\title{
A temperature increase during the Holocene Thermal Optimum triggered the development of the Funnel Beaker Culture settlement in Central Poland (Kuyavia Lakeland)
}

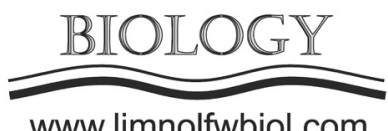

www.limnolfwbiol.com

\author{
Płóciennik M. ${ }^{1 *}$, Papiernik P. ${ }^{2}$, Kittel P. ${ }^{3}$, Gałka M. ${ }^{4}$, Makohonienko M. ${ }^{5}$, \\ Mroczkowska A. ${ }^{6}$, Apolinarska K. ${ }^{7}$, Panfil M. ${ }^{5}$, Kotrys B. ${ }^{8}$, Luoto T.P. ${ }^{9}$, Peyron O. ${ }^{10}$, \\ Krąpiec M. ${ }^{11}$, Świerk K. ${ }^{12}$ \\ ${ }^{1}$ University of Lodz, Dept. of Invert. Zool. and Hydrobiol., 12/16 Banacha St., Lodz 90-237, Poland \\ ${ }^{2}$ Museum of Archaeology and Ethnography in Lodz, 14 Wolności Sq., Lodz 91-415, Poland \\ ${ }^{3}$ University of Lodz, Dept. of Geomorph. and Palaeogeog., 88 Narutowicza St., Lodz 90-139, Poland \\ ${ }^{4}$ University of Lodz, Dept. of Geobot. and Plant Ecol., 12/16 Banacha, Lodz 90-237, Poland \\ ${ }^{5}$ Adam Mickiewicz University, Inst. of Geoeco. and Geoinfo., 10 Krygowskiego St., 61-680 Poznan, Poland \\ ${ }^{6}$ Polish Academy of Sciences, Past Landsc. Dynam. Lab., Ins. of Geogr. and Spat. Org., 51/55 Twarda St., Warsaw 00-818, Poland \\ ${ }^{7}$ Adam Mickiewicz University, Inst. of Geol., 12 Krygowskiego St., 61-680 Poznan, Poland \\ ${ }^{8}$ Pom. Branch, Polish Geological Institute - National Research Institute, 20 Wieniawskiego St., Szczecin 71-130, Poland \\ ${ }^{9}$ University of Helsinki, Ecosys. and Envir. Res. Prog., 15140 Lahti, Finland \\ ${ }^{10}$ Université de Montpellier, CNRS, IRD, EPHE, UMR 5554 ISEM, Montpellier, France \\ ${ }^{11}$ AGH University of Science and Technology, Geoph. and Envir. Prot., 30 Mickiewicza Av., 30-039 Kraków, Poland \\ ${ }^{12}$ Ist High School, 6 Mikołaja Kopernika St., Piotrków Tryb. 97-300, Poland
}

\begin{abstract}
The Wietrzychowice Cultural Park protects one of the last preserved megalithic barrows of the Funnel Beaker Culture people at the Kuyavia Lakeland (Central Poland). Archaeological excavations of the lake palaeolittoral zone were conducted on the nearby Karaśnia Lake shore. Numerous Mesolithic and Neolithic remains were excavated including: flint artefacts, potsherds, arrowheads, and mammal bones with traces of human processing. The SM9G2 core from the Śmieły site covers gyttias and peats with the Holocene history of Karaśnia Lake. The age-depth model is based on 3 AMS and 3 LSC radiocarbon dates as well as cultural remains. The bottom section of the core $(275-190 \mathrm{~cm}$ b.g.1.) includes the record of the early to mid-Holocene layers that fall on the Mesolithic and Neolithic in the region. The multi-proxy study (geochemistry, plant macrofossils, pollen, Mollusca, Cladocera and Chironomidae analyses) were conducted on the Mesolithic-Neolithic section of the core. Additionally, Chironomidae subfossil analysis was conducted on the SM1 core from another part of the Karaśnia Lake shore zone, documenting the mid-Holocene age of the lake littoral shore development.
\end{abstract}

Keywords: climate reconstruction, multi-proxy study, Mesolithic, Neolithic, peri-Baltic region

\section{Introduction and Methods}

The Kuyavia Lakeland is a crucial area for the Funnel Beaker Culture development in the southern peri-Baltic region. That territory is one of the earliest where the Mesolithic culture transformed into the Neolithic settlement in Central and Northern Europe. It was possible due to fertile soils and high landscape geodiversity. The Funnel Beaker Culture tribes developed a complex societal structure and left behind more than 200 megalithic long barrows, of which only several survived to the current times in the Karaśnia Lake surroundings. Since 2012 archaeological studies

*Corresponding author.

E-mail address: mplociennik10@outlook.com (M. Płóciennik) have been supported by palaeoenvironmental research dedicated to recognise the natural background of the Mesolithic and Neolithic settlement. The aim of these multi-proxy studies was to reconstruct climatic and habitat factors that might have facilitated or suppressed transition of the hunter-gatherer to early Neolithic economy.

\section{Results of the main palaeoenvironmental analyses}

Pollen analysis results revealed three main stages of local environmental conditions: (1) the phase 
of aquatic ecosystem indicated by the presence of Tetraedron (from 9.5 ka to $7.8 \mathrm{ka} \mathrm{cal}$. BP), (2) the phase of water shallowing which occurred between $7.8 \mathrm{ka}$ and $6.6 \mathrm{ka}$ cal. BP, and (3) the development of alder fen since c. $6.6 \mathrm{ka}$ cal. BP. During the Mesolithic Period, mixed oak and pine forests were the dominant type of natural terrestrial vegetation. The high representation of birch could be, to some extent, associated with forest transformations in the vicinity of the lake due to activity of Mesolithic communities. The early phase of the Neolithic Period, which started in the Kuyavia region c. $7.5 \mathrm{ka}$ cal. BP, did not show any other changes of vegetation cover. Significant environmental change was recorded in the Middle Neolithic, c. $6.6 \mathrm{ka}$ cal. $\mathrm{BP}$, reflected by spread of swamp habitats with alder. Smaller cultivated fields with low-pollinating species such as Triticum, Hordem or Avena could not be recorded in such conditions. We may assume that cleared, more open forests may have been used as a pastureland for livestock.

The youngest phase of the analysed sequence (dated to 5.8-5.5 ka cal. BP) shows further changes in the landscape. The observed increase of pine pollen c. 5.8 cal. BP may be actually associated with further opening of the forest canopy due to the reduction of oak and elm stands. This evidence makes us consider the possibility of an early cultural landscape as patches of primeval forests, more open park forests cleared by man, and probably some smaller patches of open land, possibly used for restricted cereal cultivation.

Plant macrofossils - numerous macrofossils of aquatic plants such as Najas marina and Nymphaea albaindicate the presence of a shallow lake zone at the sampling site. At the sediment depth between 7.5 and $7.2 \mathrm{ka}$ cal BP, disappearance of aquatic plants and an increase of rush species (Cladium mariscus) may suggest a decrease in water depth. Continuous presence of macrocharcoal pieces between between 8.9 and $6.6 \mathrm{ka}$ cal BP indicates local fire events at the coastal zone. Since ca. 6.5 ka cal BP, Alnus glutinosa macrofossils and a lower amount of charcoal pieces were recorded, which may indicate regeneration of forest on the lakeshore.

The Early to Mid-Holocene Chironomidae communities consist of warm-stenotherm taxa preferring eutrophic stagnant waters. The majority are phytophile taxa including species mining plant tissues. Soft, organic bottom dwellers are the second dominant group. The temperature reconstructions indicate mild summer air temperature during the Mesolithic and Middle Neolithic (15.9-16.8 ${ }^{\circ} \mathrm{C}$ ) (ca. $\left.7.7 \mathrm{ka} \mathrm{cal.} \mathrm{BP}\right)$ with a substantial rise ca. $5.9 \mathrm{ka}$ cal. BP Bond event (no. 4) to $17.6-17.8^{\circ} \mathrm{C}$.

\section{Discussion and conclusions}

The neolithisation extension to Scandinavia from the southern peri-Baltic region is correlated with 5.9 ka event (Warden et al., 2017). Our research indicates that during the Early to Mid-Holocene, before the Funnel Beaker Culture settlement, climate warming occurred at the same time in Central Poland as well. We hypothesise that the ca. $1.5-2^{\circ} \mathrm{C}$ increase in mean summer temperatures played a crucial role in dissemination of extensive cultivation and stock breeding as well as primitive gardening introduced by the Funnel Beaker Culture community in the wide area of Central European Lowlands.

\section{References}

Warden L., Moros M., Neumann T. et al. 2017. Climate induced human demographic and cultural change in northern Europe during the mid-Holocene. Scientific Reports 7: 15251. DOI:10.1038/s41598-017-14353-5 